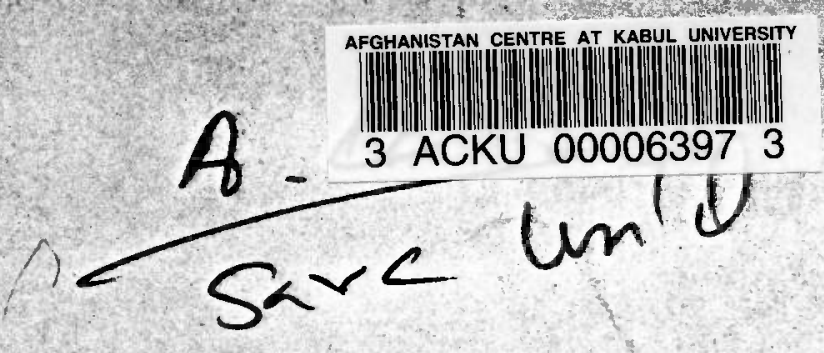

$333.3-84 A 1001$

\title{
ANT ASSESSTIYYTI
}

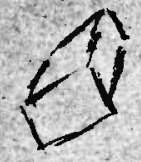

of the

HEI IIAND ARGHANDA3 VALTIY REGICE

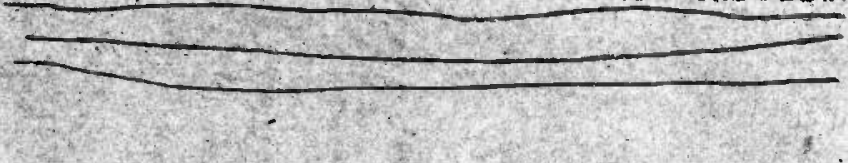

Fir ex Jraft for Corme:sis by HATA and घSAD

$$
\begin{aligned}
& \text { Submirad by: Loxis a Mteheil } \\
& \text { Dwtd S Gophes } \\
& \text { Aertsors, Frand Devolopmat } \\
& 2 \operatorname{santan~} 1303
\end{aligned}
$$

PROPERTY OF

OFFICE OF AID/REP LIBRARY 


\section{Introduction}

i. Two Prinatsy Cowlusions

A. Begtonit Pkan

3. Inm rarad Tand and Water. Wanagertent

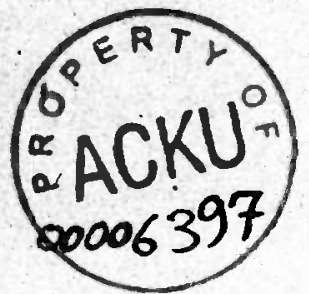

III. Four prisusy Recommendations

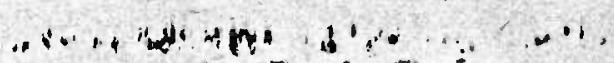

A. Brsin Suroty

B. Srangthened Office of Pianning and Sratigtios

C. Approrisate Water Charges

D. Furmer Eduraticu

IV. Cbser asions

A. UIJID Ansistace

B. The Feluand Arghandab Valley authoxity

i. Tlanning

2. Sudgeting

3. Serscondel

1. HAVA Relatconshos whin Gocal parners

5. HAVA Relatiousinp Wít Arghondab Area

6. Artension and Farres Eduedtion

7. Wortioulure

S. Ltresion 
iv. Cbsorvations - continued

C. Agrioultural Business and Marketing

D. Lrabor and Afechanization

1. Eeary equinraent

8. Trerm mechamizaiton

E. Crodit

F. Electric Pesunt 
1. MTRODLCTION

The Vulted Siates rauts to condinue to help derelop the Eelnand Arghandab

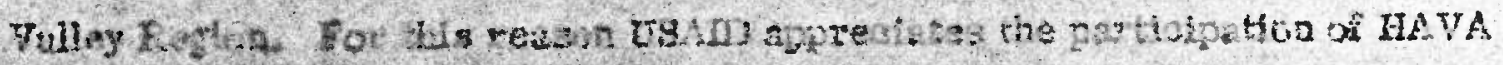

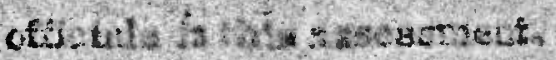

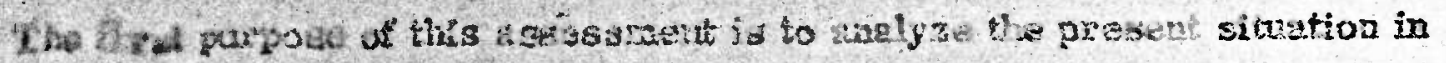

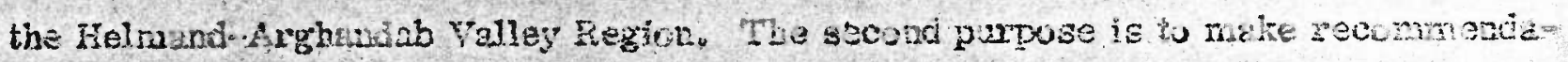

tions and sumectoas which might be beteijcial for the ptitre.

Iuforme ens bas been gathered rum HAVA officials and USAD teshictans.

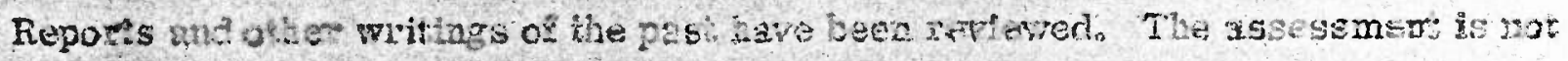

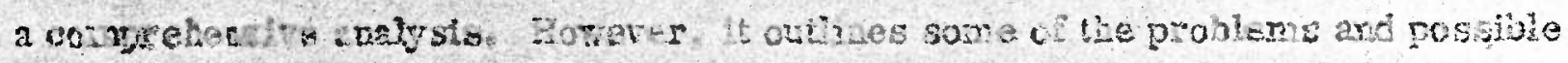

Eolubag for twrther vegical develuphent,

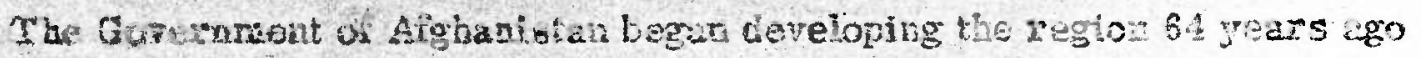

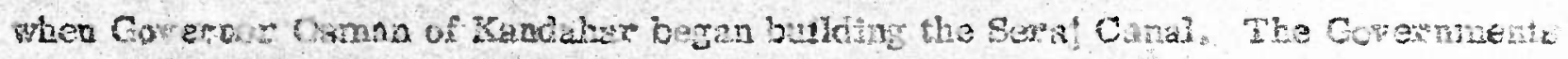

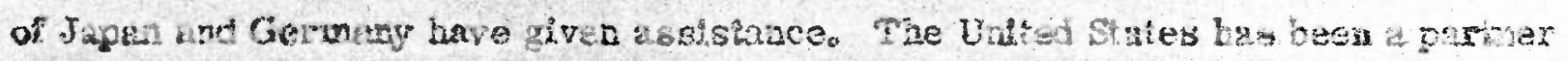

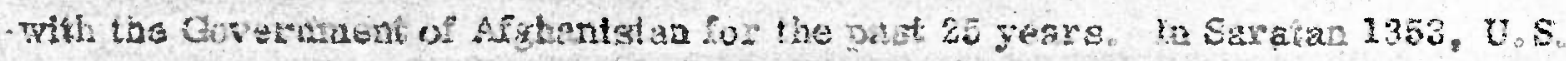

projaci assistuhce will ferminate. 


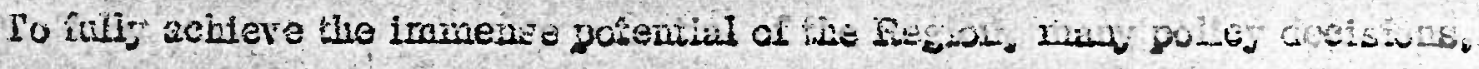
many moaths and years of careful planming, and muxh work is needeú.

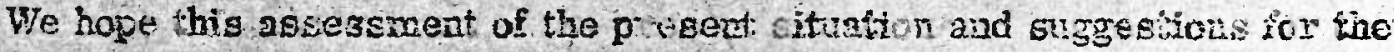
fitsure wlll be hejpful.

\section{TWO FRINA PY CONCLUSTOINS}

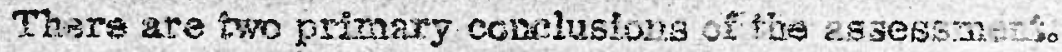

First, a comprehensive developroent plan is needed for th Helumat Aryantet

\section{Valley Regioa.}

Selond, the manageinent of land and water regurder zesds to be inyroved,

A. A Refiunal Plan

The Governont of Afghaistan began woris the Begton in 1290 . The

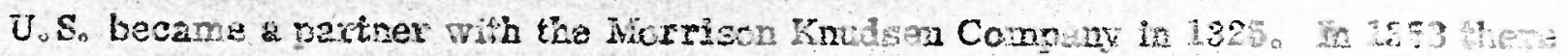

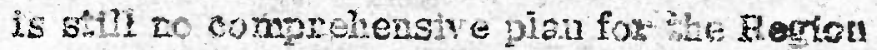

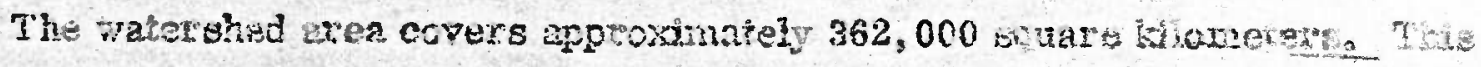

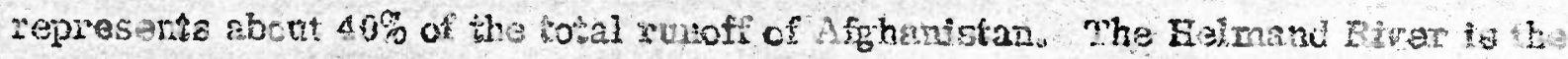

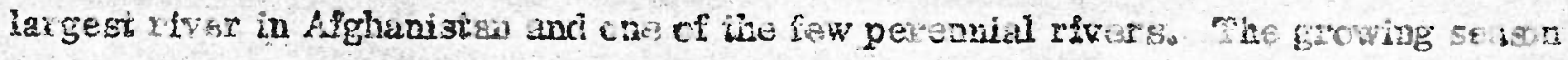


for the Region is 10 warm months. The daily period of levat light intecsity and

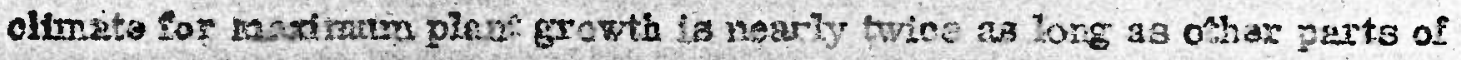

Afghingiviza.

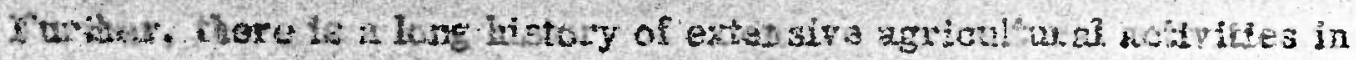

the Region, dating baek by some estimates for 5 , coo years. Nine huered yeor

argo, under the Sultans Seburtigin, Mainat wad Hasud, it pas one o be nost

productive and powerful testons of the Chatuavid Empire.

The estmeted irrigable land ared is 260,000 heciaes. The is $25 \%$ of

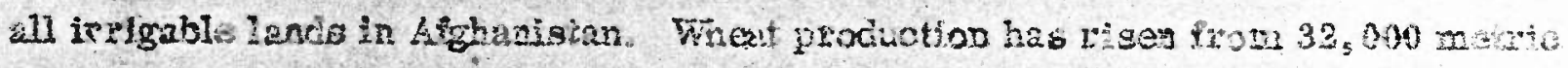

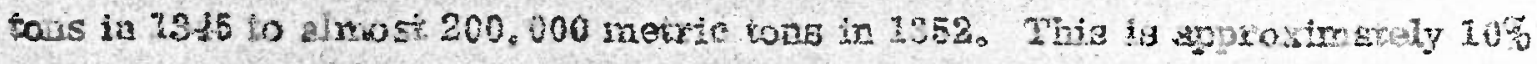

of the countrg's total wheat production.

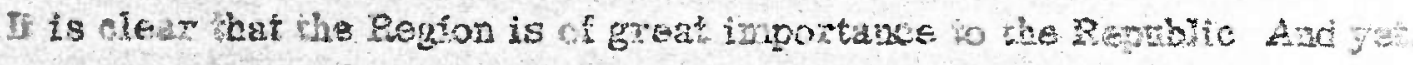

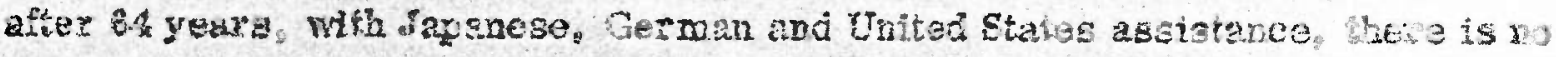

comprehonate plan to expit the greet reacurces of the Rerion.

Tug additional costis for full development of the Regico are unison 


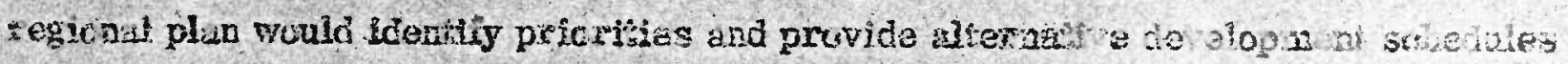

on the basis of resources.

The grea whteh is in the WAVA is not cleer. This is one more retson for a

regionul plan. Some say the Arghandab ared is in hle Thegicn. Some say it is not.

Frme say the Chairansuz Basin is lit the Rerion, Fome say is is not tand is

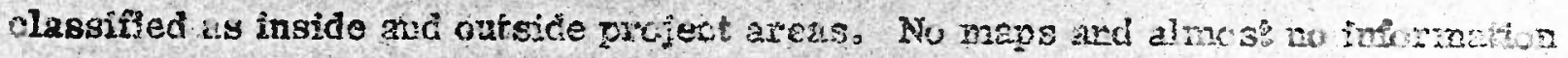

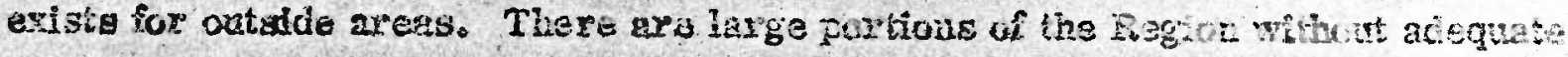

maps, and no detauled man of the totat Region axists. Thar are no adlaghate

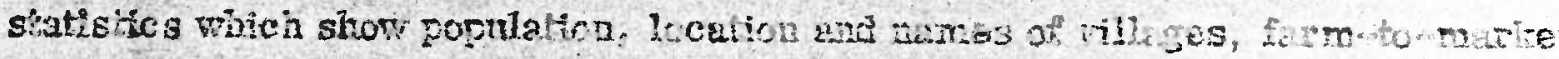

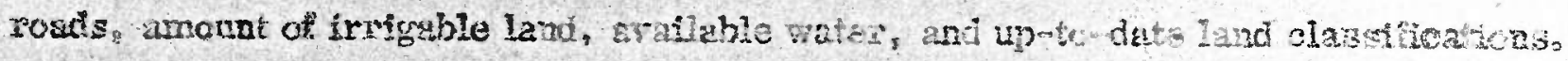

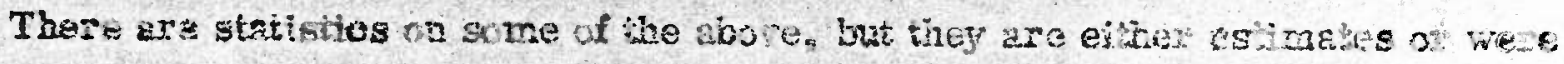

complisd $20-25$ jears ago or both.

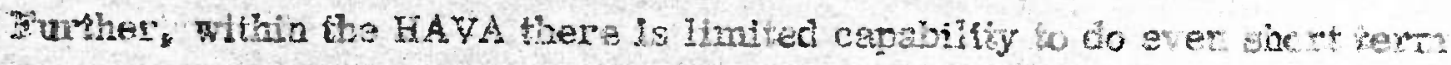

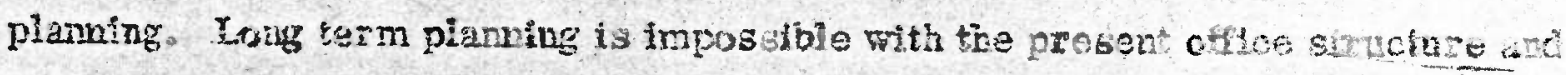

number of guslified perisonne? 


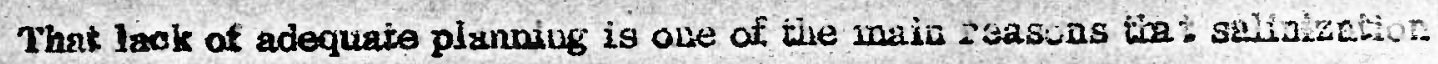
and raterlagging have become suib big problems. In 1335 whan ine Gorernuent: first cuntrected wth Morrleat Kindser for constriction of he Boglia ivialse and

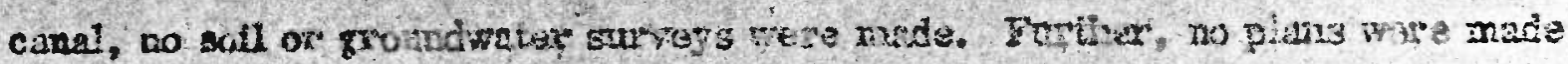
for hew aftilexs and no plang vere mace for he farmers alveady on the lind.

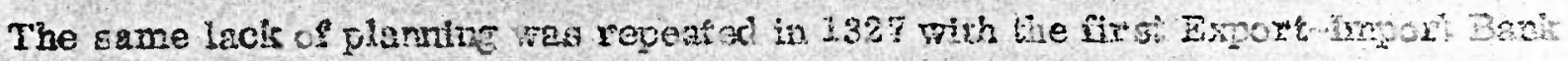

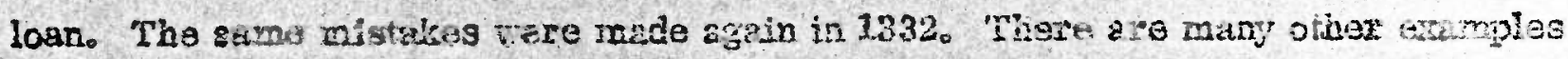
af porr glanting thich have caused pesent problews. Foor planuirg in ine turne

will contluus to rnisallcoave resources

B. Grortred Innd and Veter lwanasement

Tho anost soricus obstacle facing the Reging sovelopment is the

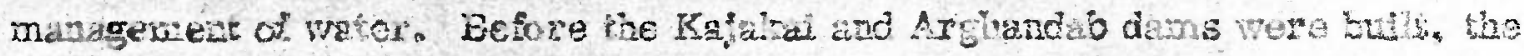
farnexs of the Feln

The Iand and water resources way have heen if 3alanie. Trabitonaly se favmers medsered lend by luw much seed they soved each yest, and they left

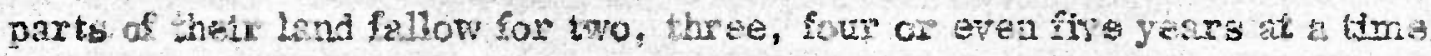


before they plunted ark, ther crup ou tt. This long sallow period left plenty of tims for the irrigation vider to drain awiy. Iand did pot waterlog, aid the eall bed timte to lesti ntrat:

The extsence of a year wond water entply upset thes bulance. A scax:e and puluable resiuree was suddenly cleap and planfiful. Fosshly for the first thme in that ltres the farmata had more water than they keew how to ust. This

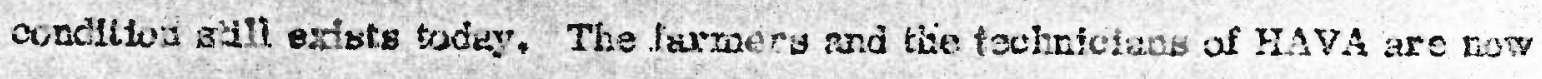

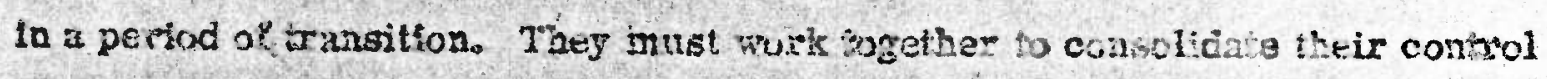
of year-round watar.

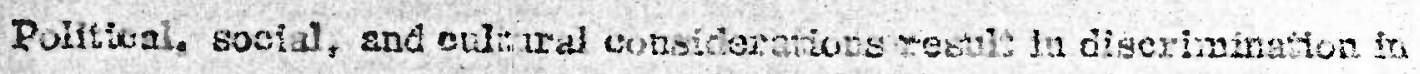

the use of water. Toc much vater is applied to latd near the soures of the cunals and hoc lithle water is aratible al the end on This has reauced tyop land and

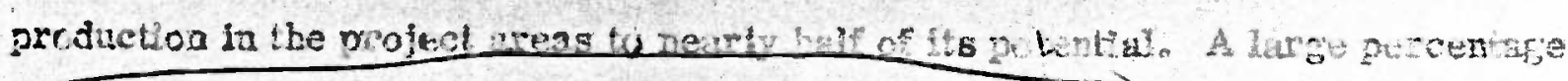

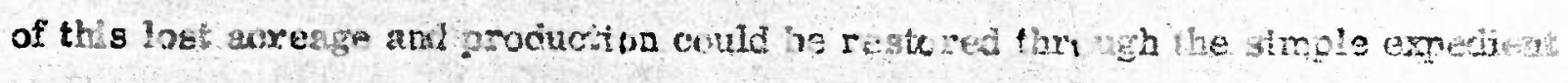
of condoly over the use of trater.

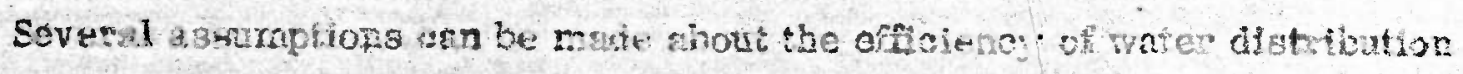


to the farmers. Fi 3 , the losses tu he canal's are assuined to be 25 percent, and the loases in the joraruls 25 parcent. A $25 \%$ lose is alculatid loit form westo. This

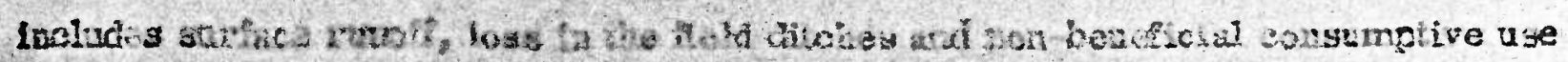

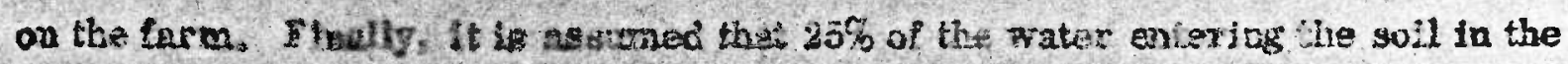
crops' rook youes is ect uged by the glent. It to lost to deep pervalation. Part of this wuer is ulso neguirod Lot leaching. When these losses axe aplled bey what a field eftrolency of $56 \%$, 2 farm efficiency of $18 \%$, ind a project afficienay of $30 \%$

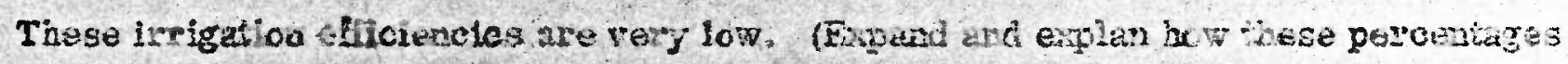
were derited.)

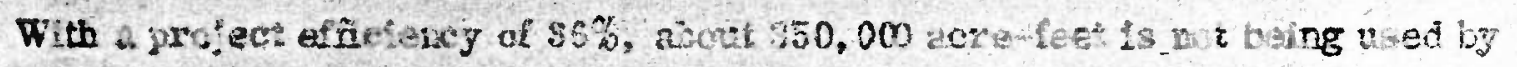
the crops in the Axgitarcieb region. Fhis could bo uned to Lragete ar gdditunas number of leribs, In the Heimand Vailey with a projert efficie oxy of (10.

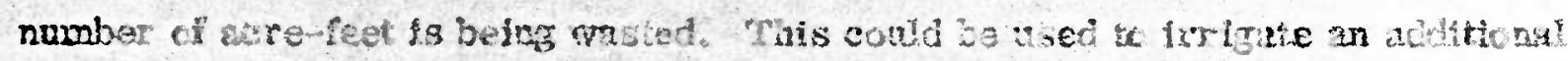
numbar of jeriós.

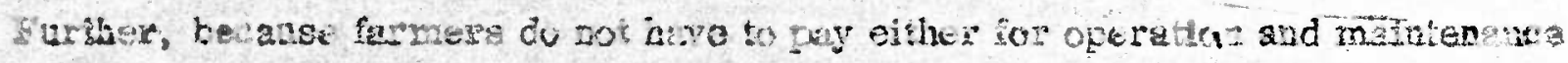

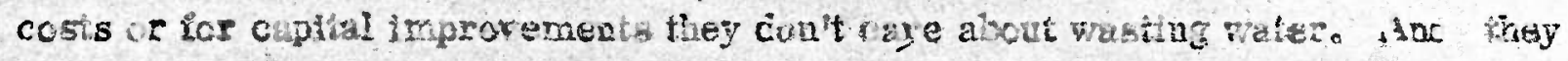


don't boiher abcus: clogged and imprcperly maintained draine.

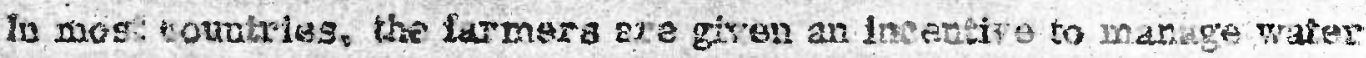

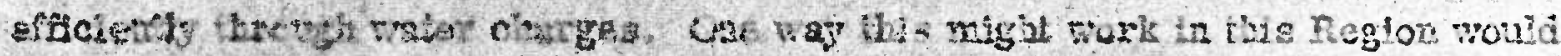

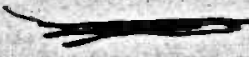

be for ezoh faimer lo seceke all allocubion at a set fee for so many aere féf jerio

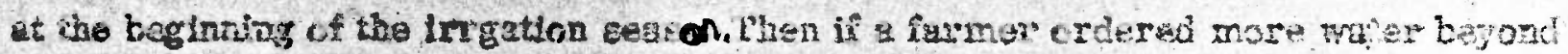

his allocation he could be chergeil ed adcitional fee.

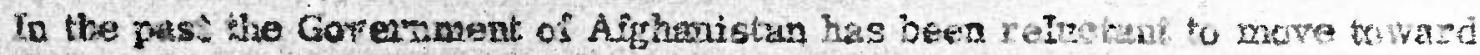

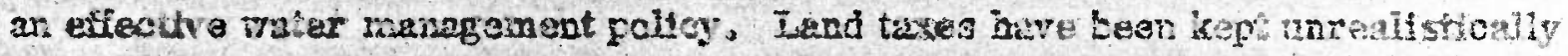

10\%. They hato been based on a lund ulasdricatin guvey cone in 1307 . There tos

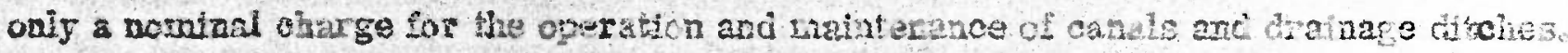

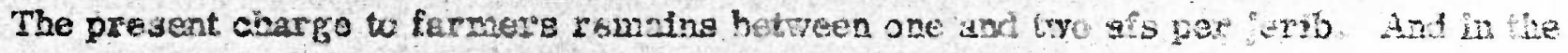

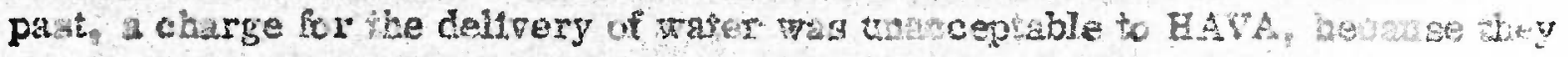

feared ogoosilion from the rarner:

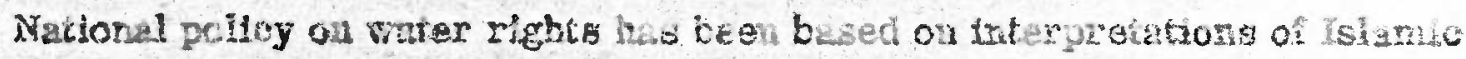

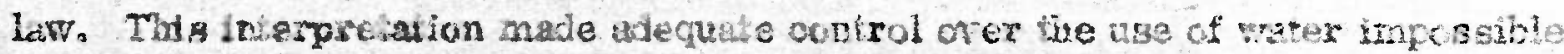

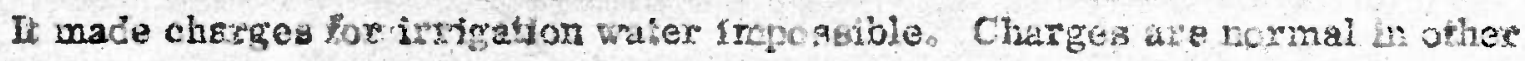




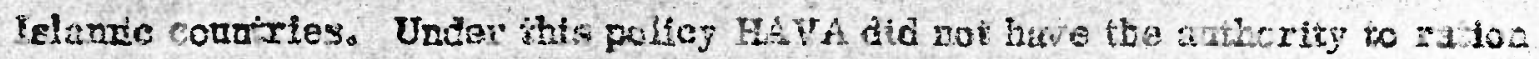

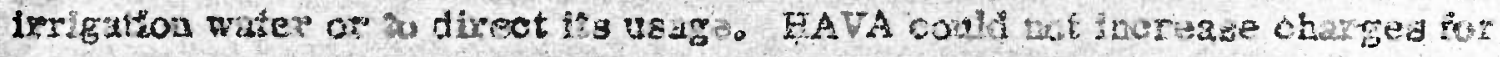

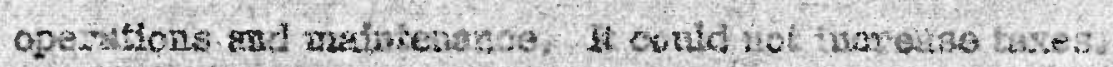

This polley was based on prilleal revity, It ras nut baged oz strict

iffeology. Naticnelly wery effor: was wacte to stoit? change, Change might catase

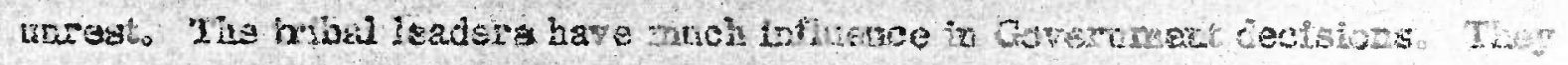

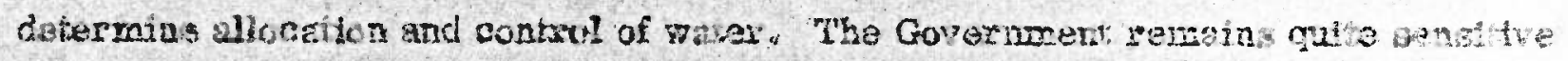

to thatr cfinion aud complaint3.

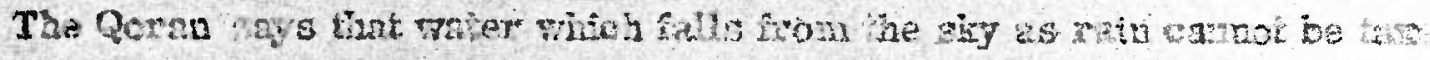

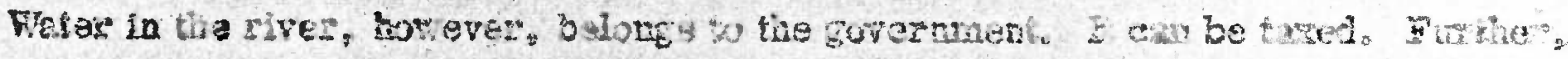

when water is divered throteh a caul, if thes labor and nower bo buld thts

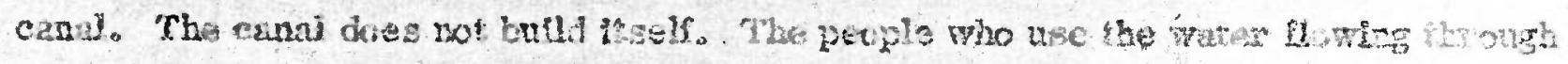

the cand cas be charged for this lubort and money.

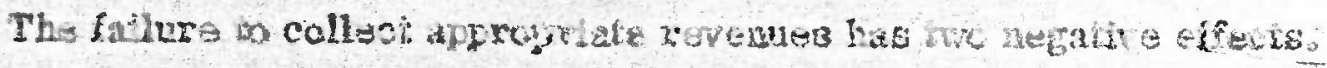

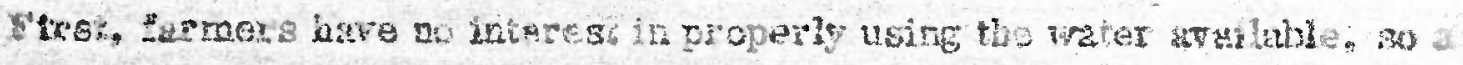

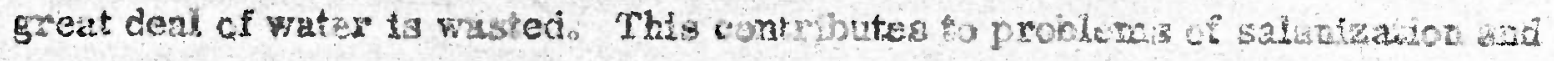

water logging 


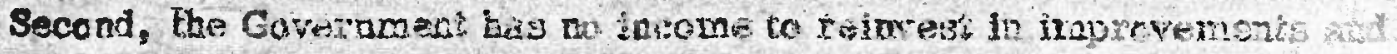

maintenance. Th: Government has to conilnue spending funcis from the Ceatral

reasury.

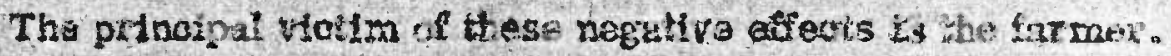

\section{TOLR PAIMLAY RECONIENDATIONS}

RECOMYMENDATION NO, I

The Government should conulissiou a study for the Felmand Atghandeb

Valkey Basin Inohding the Chalsansur and Feishan area.

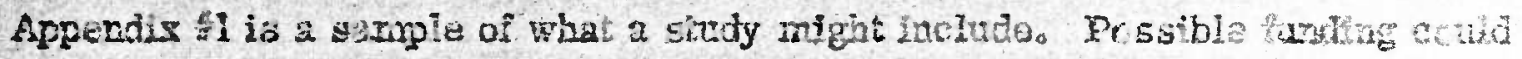

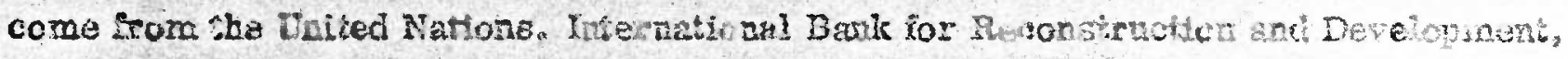

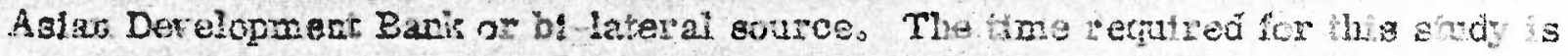

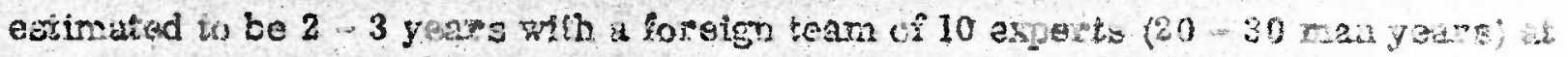

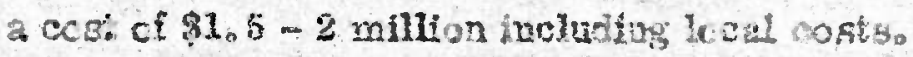

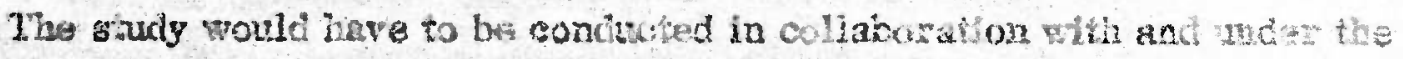

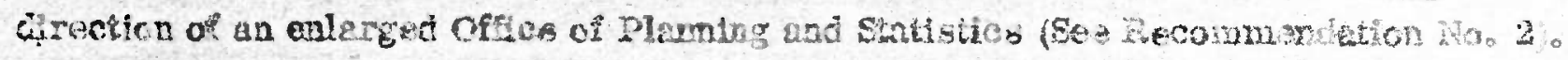


RECONMENTATION NO. 2

HAVA should increase the staff and authurity of the office of Planning

and Stutistics.

An guthoritative office whbin HAVA is neated to dires : basin gtudy so the

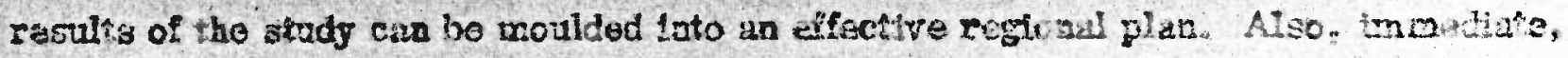

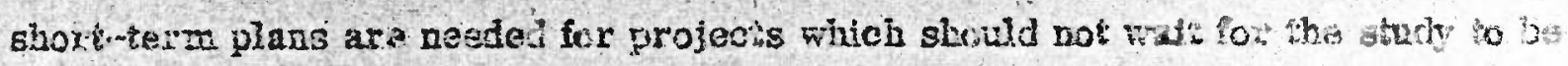

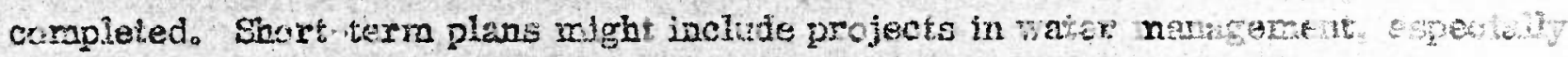
new and inproved drainge consiruction and maintenance, livestol, extonston and

farmer educutce and agro-business.

\section{RECCMINENDATION NO, 3}

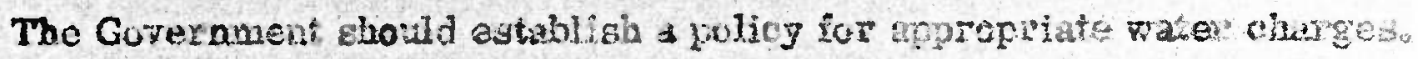

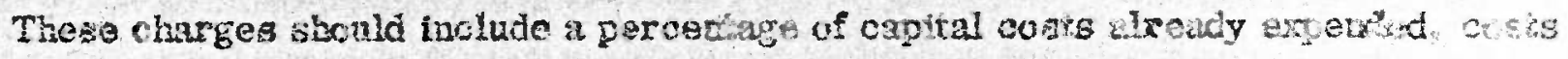

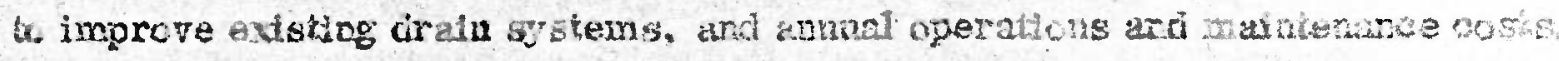
EECONMENDATION NO 4

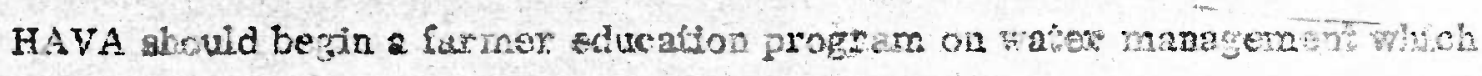

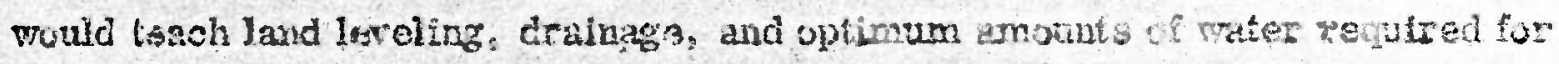

purticular ezops. 
W. PBSERYATIONS

\section{A. USAID ASEIsiancE}

If $\mathrm{U}_{0} \mathrm{~S}$, ecsigfarde is requetsed in the rature tor the Hegim, three

observattuns sinculd be consideret.

1. USAD assistance noeds to bo progremned in oluse collahoration

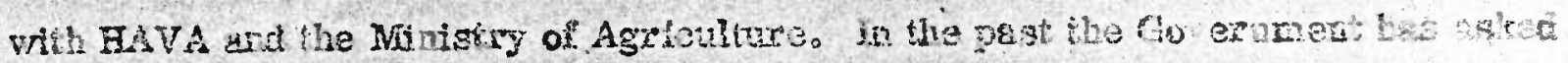

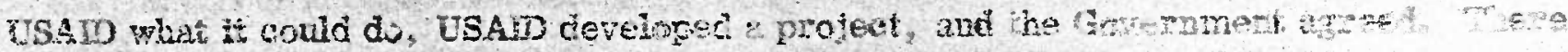

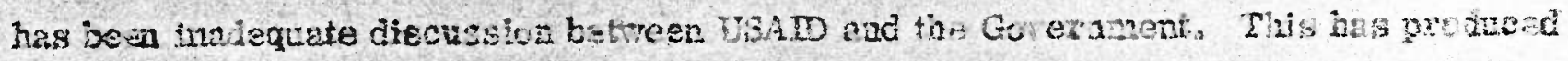

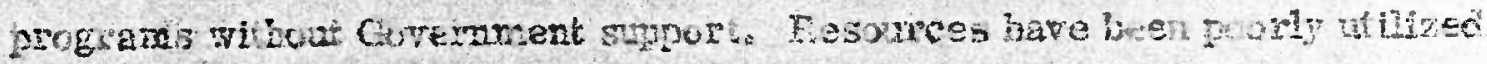

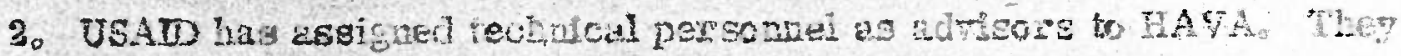

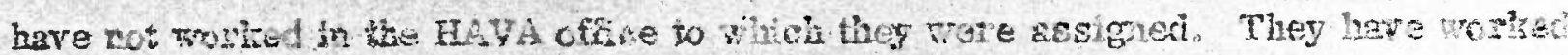

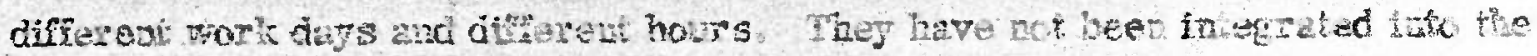

operations of KAVA

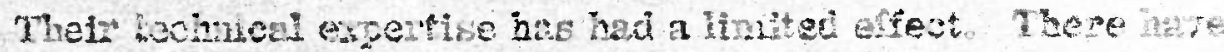

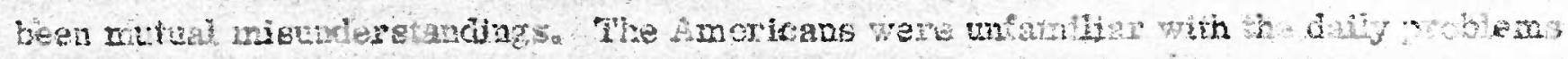

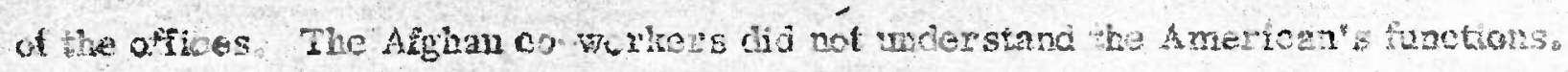




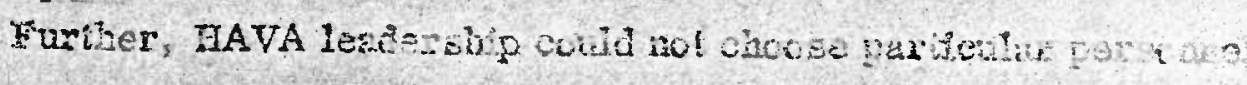

assigned.

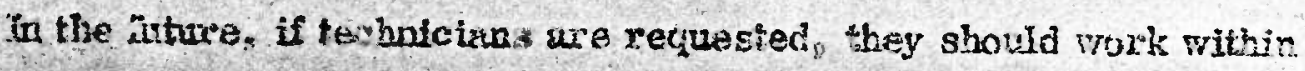

the sppropriate office of their cousterpurta. They should rork the same days aws

hours. They shuld be part of the dally operations. They should purificipate in

policy decisions. FAVA leadership should Gikp USAD geleat personna?.

3. U.S. aEsistance siould be progranmed in the contexe of $\mathrm{HA}$ A phat

and priorities. Witbout an arthoritative Xfrice of pianning and Statskics U。 S.

assistance will focus upon neads as sean by particular offices of WAVA and the

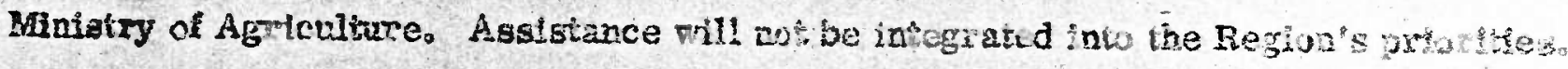

In the pas, itro years, for example, there hare been six USAD drectors tog tha

Reglon atd thres HATA Geveral Fresidentb. Progeamaing and planurg have hat

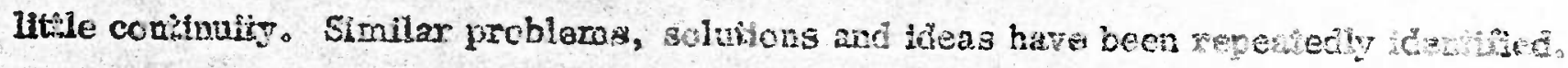

We hare contiaud to reinyent the whesi.

B. The Reimand Arghaidab Vailey Authoris

The HAVA originally was eatibil hed to seftie anew families on lasd a

the regicn. 148 functions have increased over the years. Th area of resporsibnty 


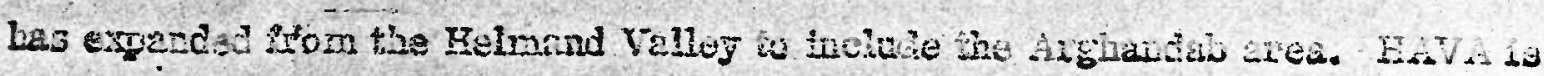

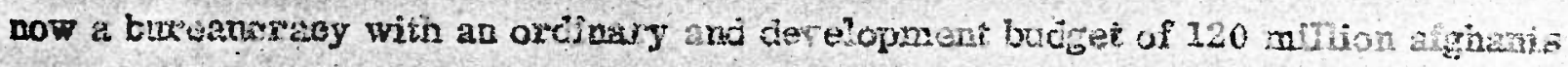

per year and 2,600 governmen and echimet empleyees.

HAVA plsaning and budgoting sy stems are deisient. in zddition, there are

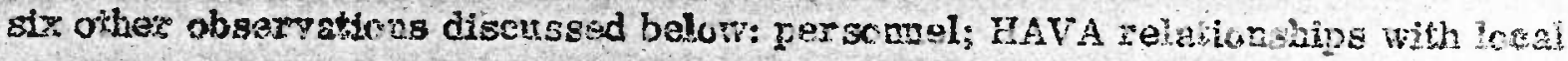

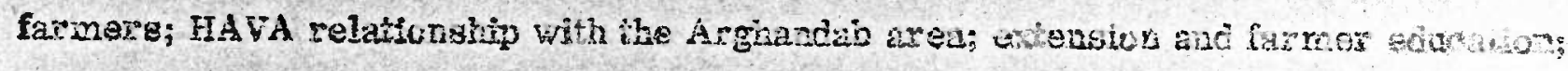

bordcultare; and Hresiock.

\section{Plasining}

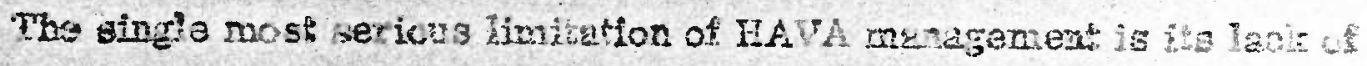

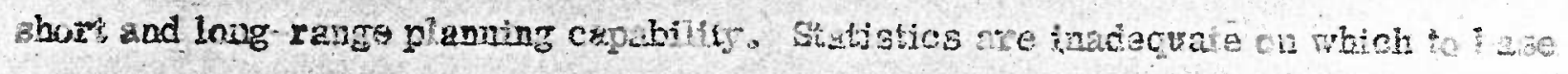

good management decisions. No cffice has the restures or guthonity to rectanong

pricities fox davelopraen intestmedis.

\section{Eucigeting}

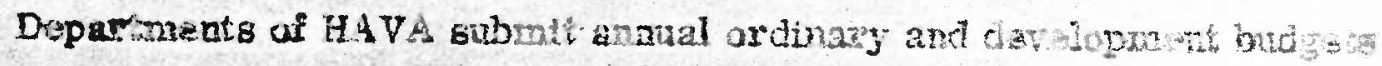

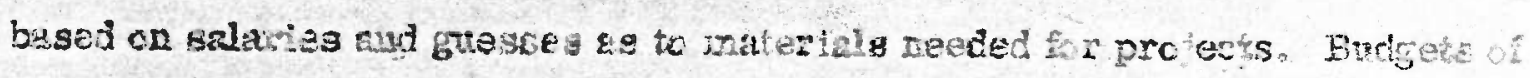

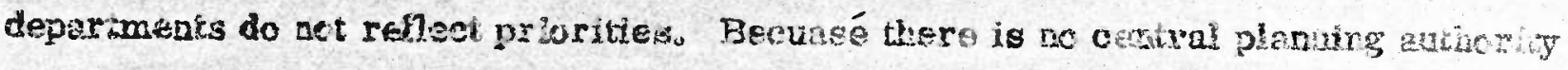


budget review is limited to comparison with previous expenditures. Budgeting

is a programming process. It should be a managenter bocl to focus prioxitus

\section{for the entire agency.}

\section{Pereonnel}

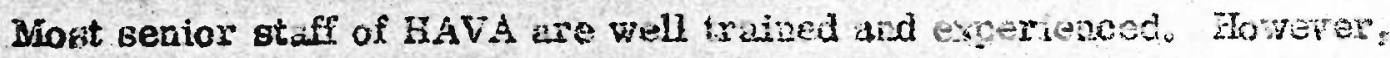

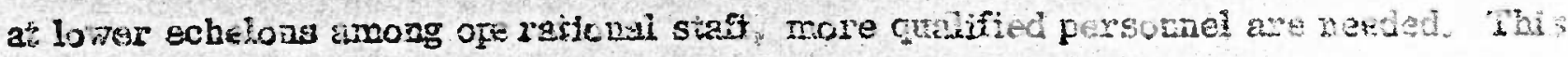
involves recruing new personnel and bether on the-job training the most striltut

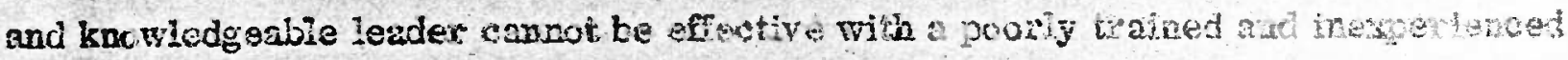

stain.

4. HAYA relutionships with lo a farmegs

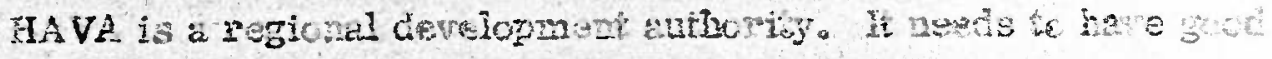

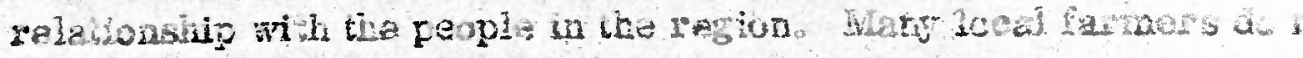

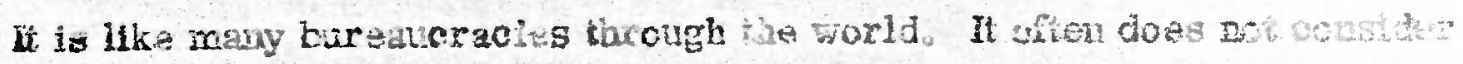

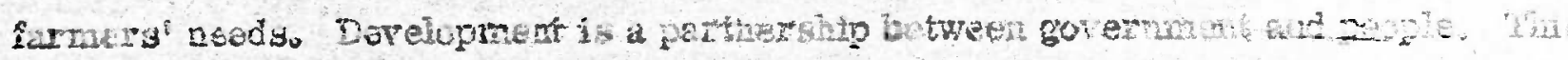

pariber hip is welk at the gresentima. 


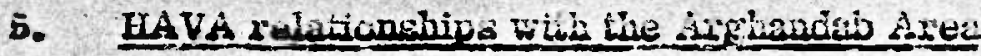

The Helmand and Axghardab valleys are net boriogendous. They have gome

things to common. Fith depend on trrigatiun gyetems. Both need estensive drainduge

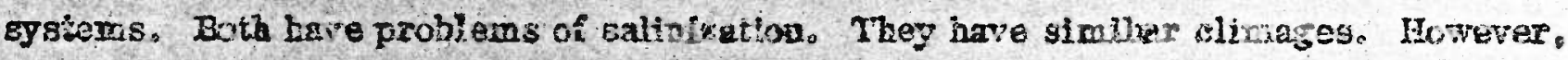
they are at diffe:ent stages of developnent. They have differ ant ratios of sharectoppess

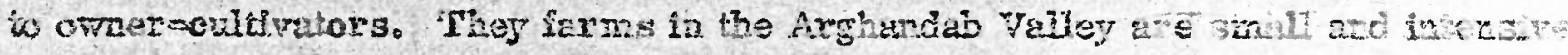

The tarms in the Felmand Valley ure large wad extenisive.

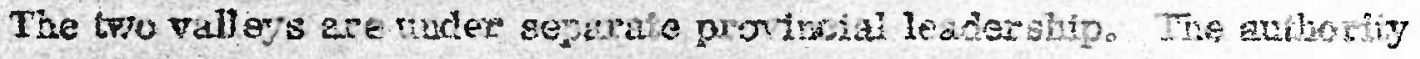

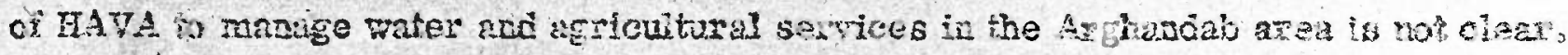

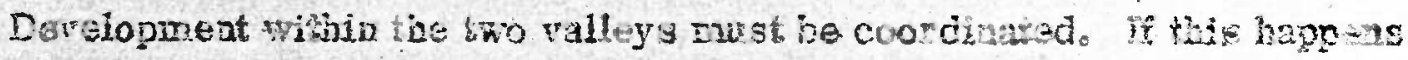

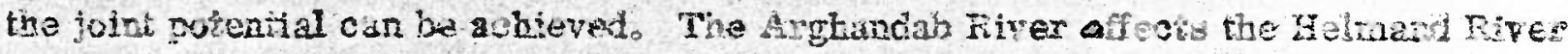

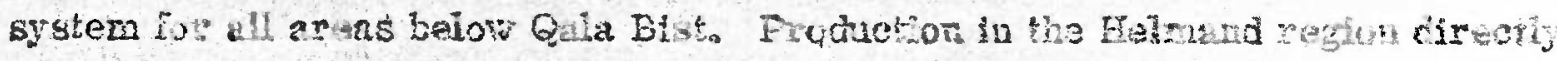

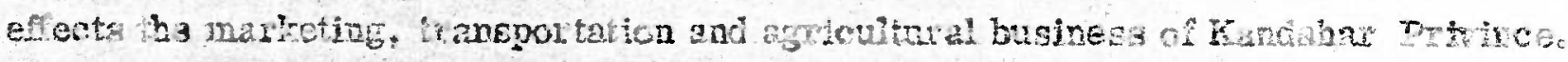
There are differences between the two ralleys, but planiag a dd dect sons mus be closely cuordinatad. 
6. Extelgion and farpare giveation

\section{a. Agroteulfure Exteusicia}

In the Helmand area thors are an estinatect 16,000 tarm femilles.

There are an estirnated 23,000 buzgar familes. These farvers, buzgats and families

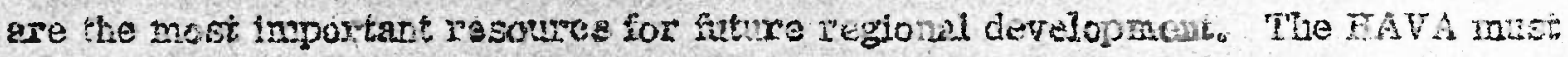

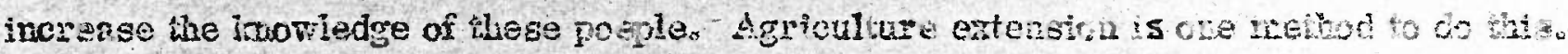

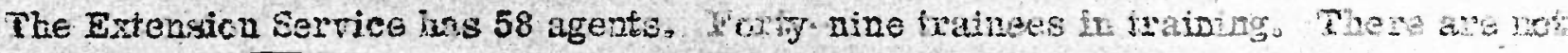

enough atghis to reach this laxge popilutton. Brore agenis asd more trairiag cive

necessary.

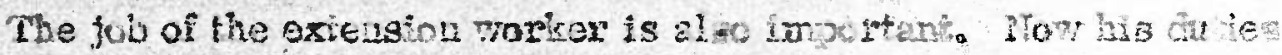

include gahering statisites, sut Thers

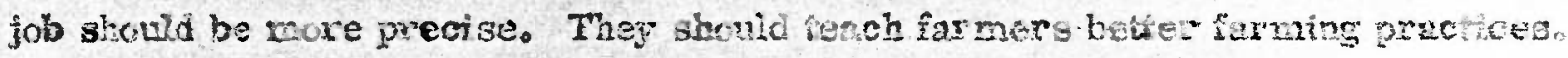

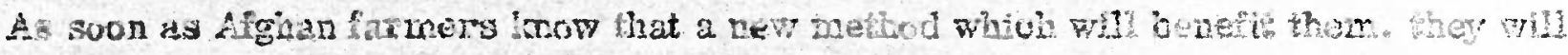

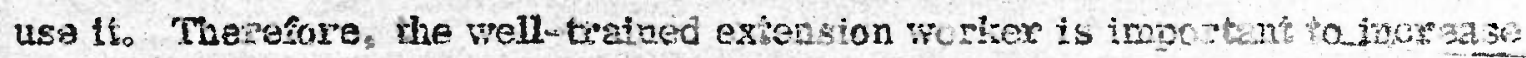

produetten and diersify crops. 
b. Laxmer Lảucation

The excansion service will never be big eanghh to seach gll haw

femilies. Tha extsnsion sexrice cannot nodmoire egricultare along. Acult or

farm education in also necessary, This education dees no happre fu biassmoons.

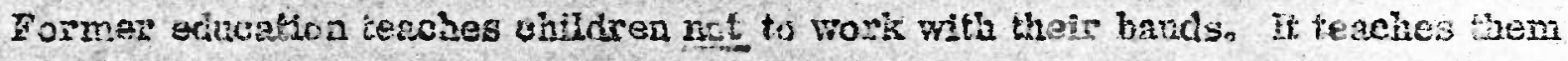

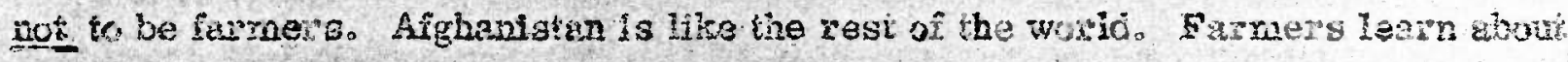

crops, land, water, inalntenance of furm machleery, health, nutrition, Iir st aic

from their frienilg, neighbors, fanily, and community leacers. The communenglon

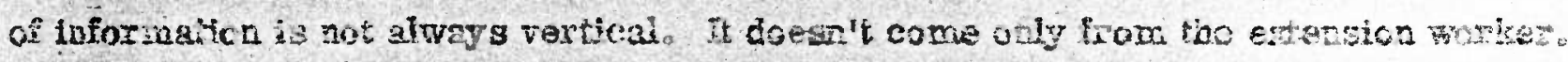

It is also borizchit. it comes from other members of the comsunity.

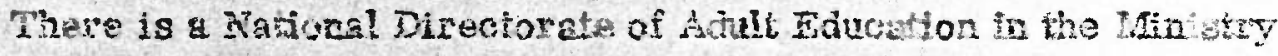

af Education The Directorate has programis in Generel areas of the cutumy th

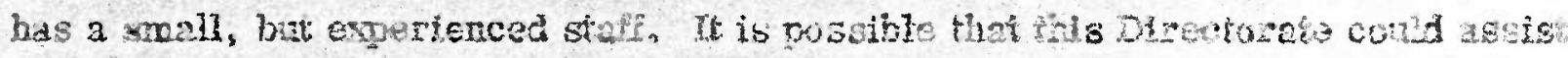

HAVA bo dereloping an adih odicahor progran. This would applemant the

Erisension Service.

To supplemed extension and adult education, the Govennen. 


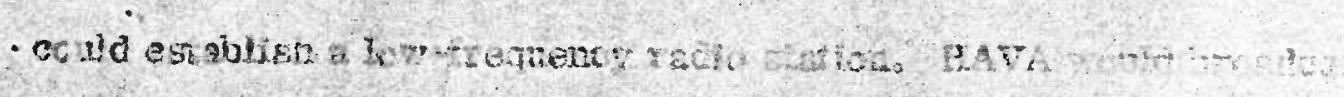

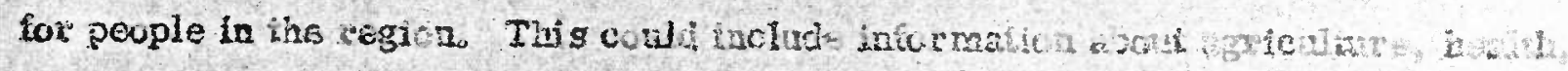

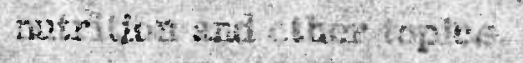

\section{PI 1 isculture}

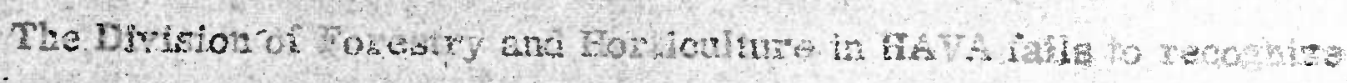

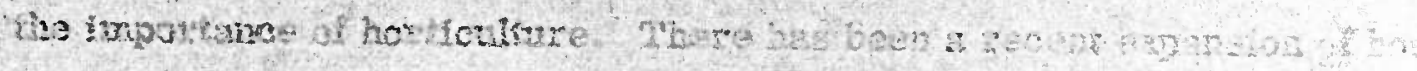

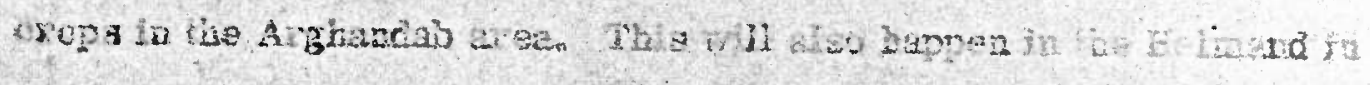

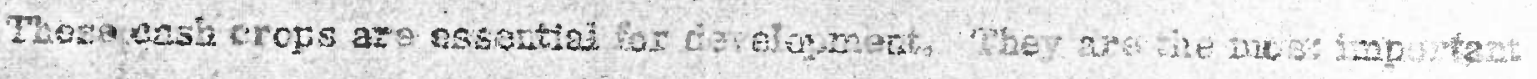

crips foc the tarme

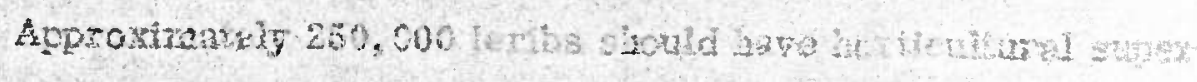

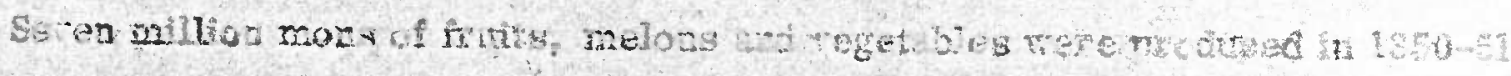

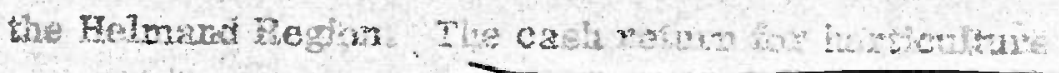

juatura tor whert

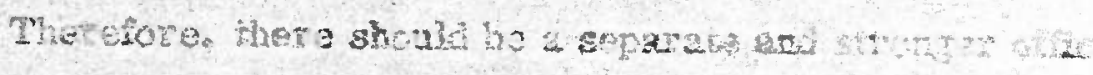

4. Lirester:

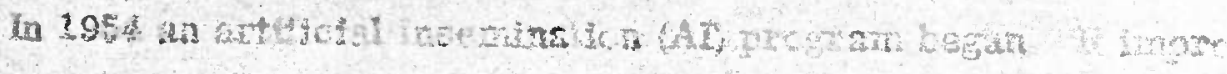


loval breeds. Brahinan, Brown-Swias aud holotain-Frefeen have bes cresaco with Kanciahure, Sîstadi, Kunari and local ercss-breeds, This progran is

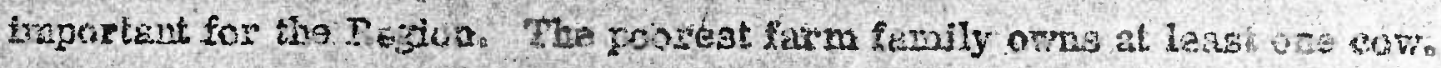

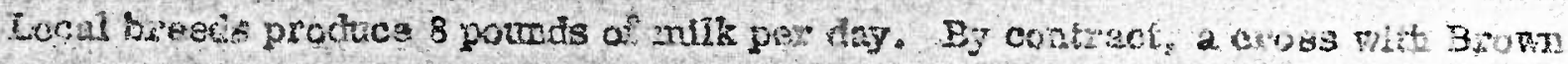
Strise, will produce so pounds par day.

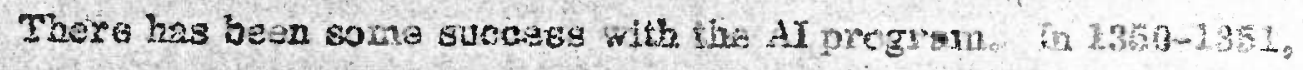

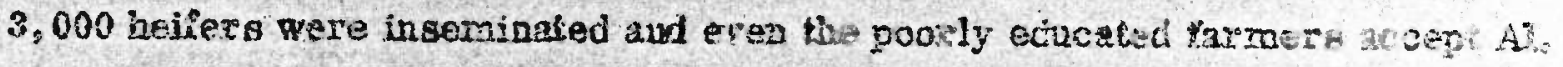

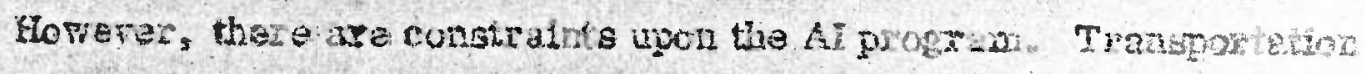

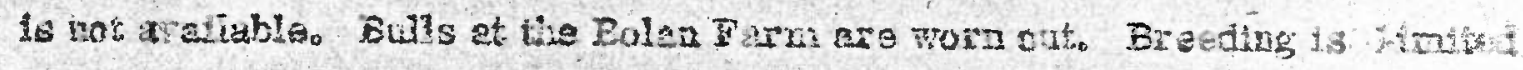

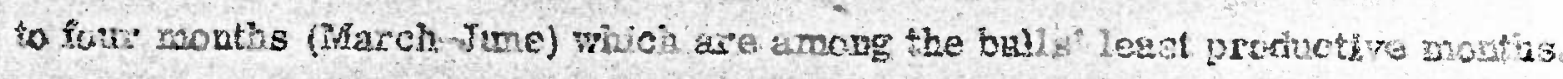

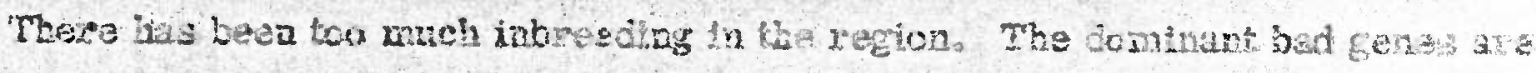

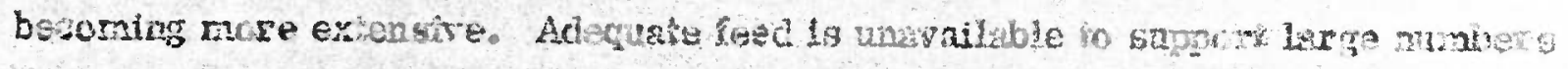

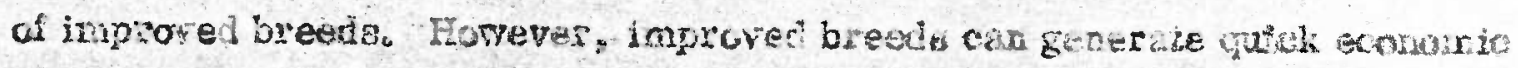

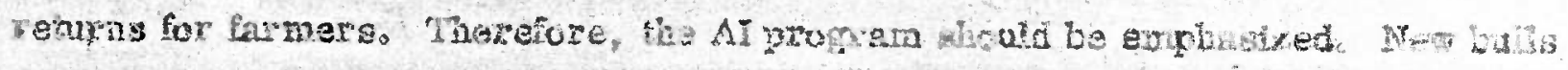

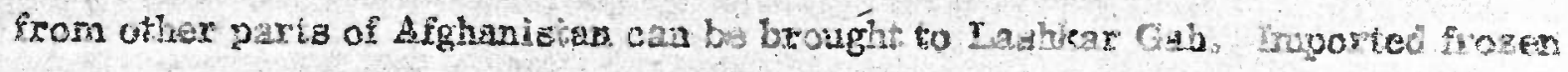


semea could alse be used economicaily. Farmers would zay for ins wivatio

c. Agrlouluurd Eusiness and Ma mheing

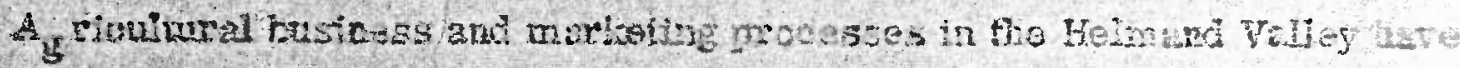

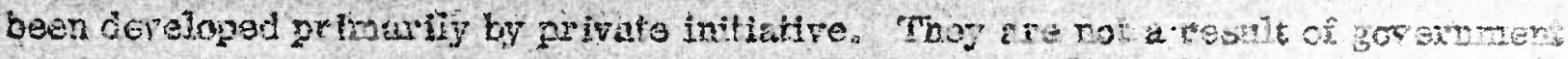

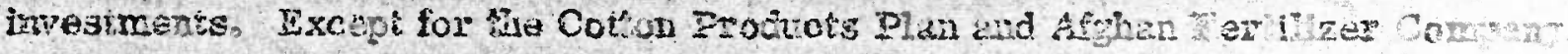

all agro busidees is prinztely owned and operated.

There are approsimately 104 grain dealers in Lashisar Gah Thay andog

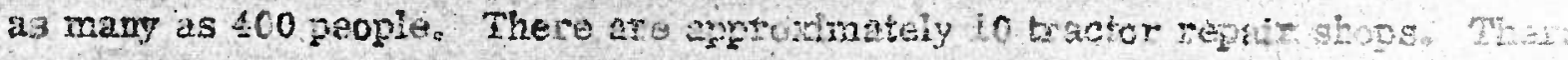

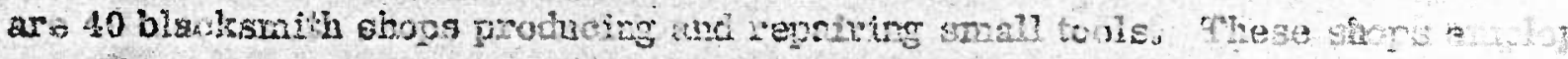

a tohal cf sporoxinately 250 people.

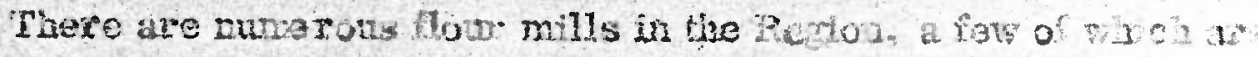

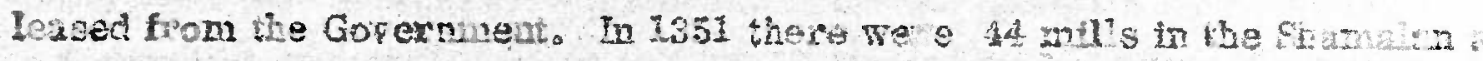

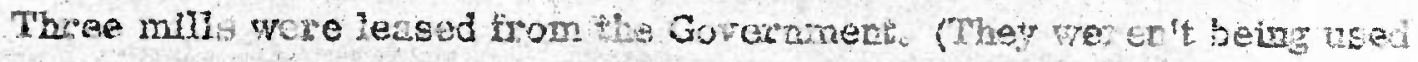

(Ses Appendix ........).

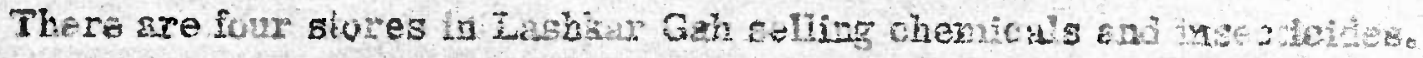

Coe fo owned and operated by the Afgion Fertilizer Compung, me thes thes 


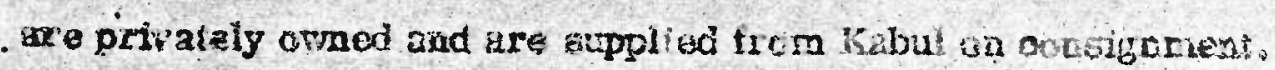

There are two ralsin processing plants in Kradaha:. Oae is oll and one

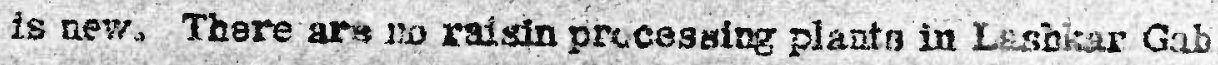

In the past the Govarament built a magi processing plant fu ciute il and

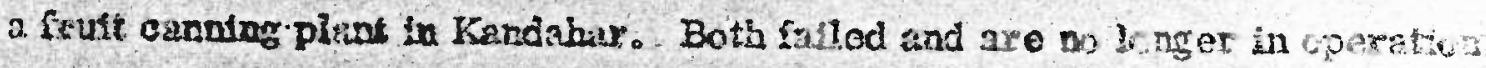

The Cotton PIant has he capacto s gu 25,000 moric tons af seed cotol

per yea: To resch this caparib it must gin 24 both per day for far motho

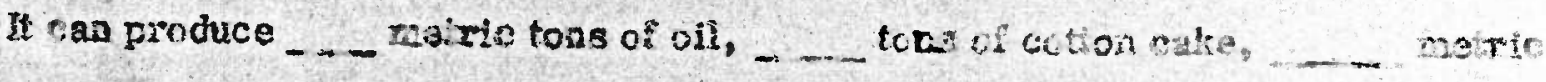

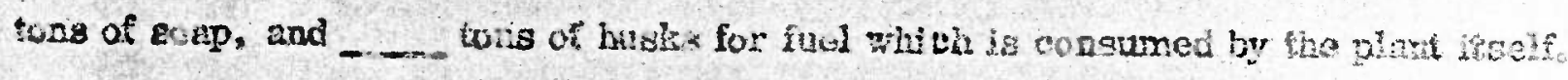

The phat diswbut oe weed froe to the farmel the ugh loual cotsua cen as

The fuctory prediets saed cotbon production at $14 \mathrm{mitrit}$ tong por ton of cothe seca

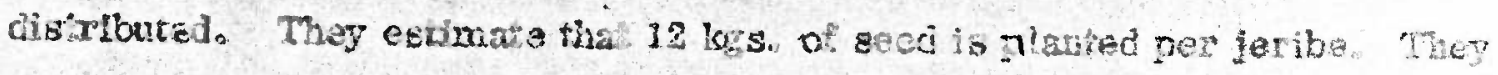

Egtinate that 1, 400 rons of seed will be Histributad in $.1552-53$

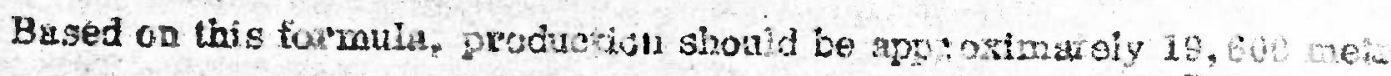

tons. The farmers will plaut 116, 367 foribes.

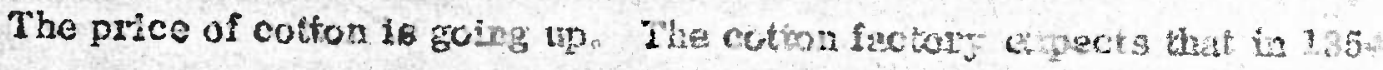




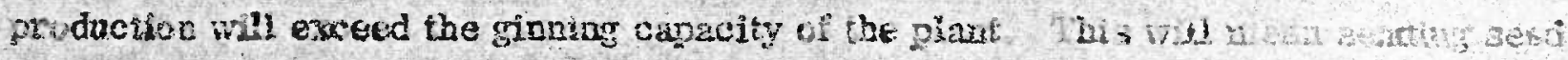

costcn out of Lashlcar Gah, installing another gin, or iscruasing locai stcrage

\section{farilisies.}

Agru buafness haz expanded ragidly áning sue past fire years becense of

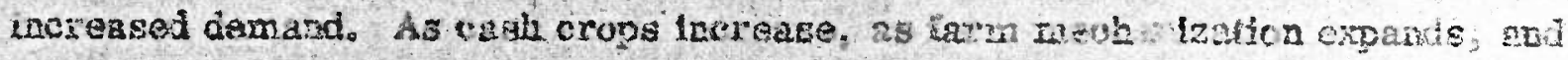

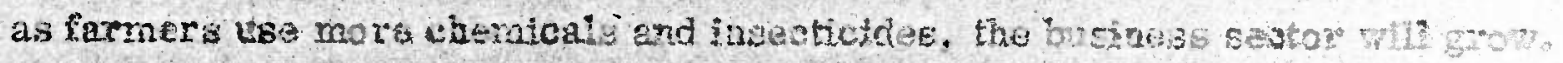

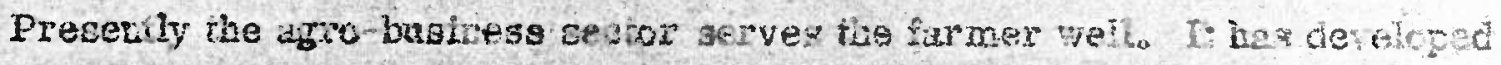

xesponse to nead.

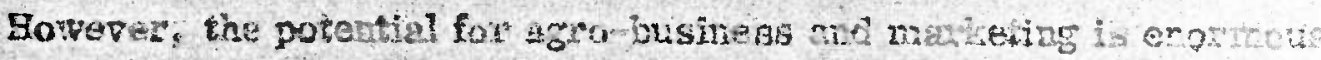

For instance, the Helmand Regton is ideat for corn prociuction. The plinate

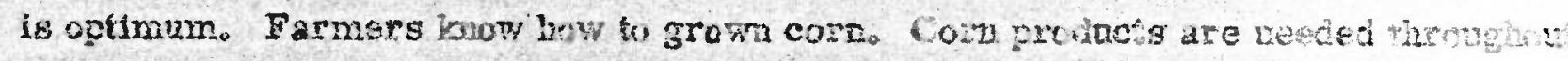

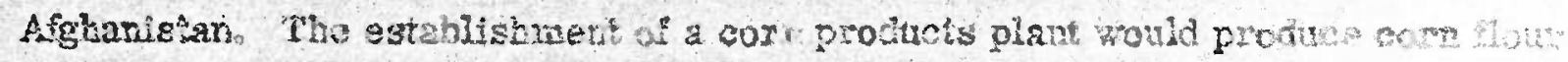

syzup, sterch, oil end cotion ceed.

However, there ere prindry constrints fo tul cavelopent of the

Egro business and maket ting sector: 


\section{3.}

4.

5.

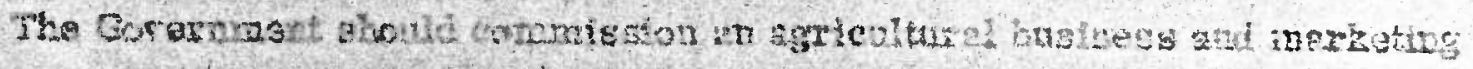

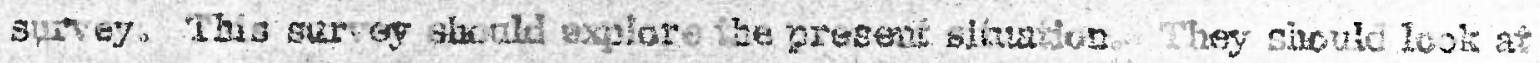

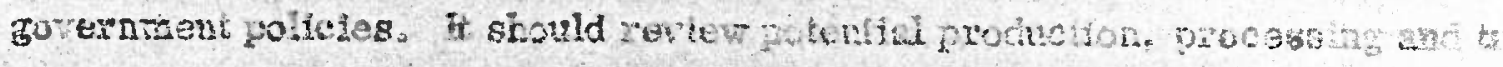

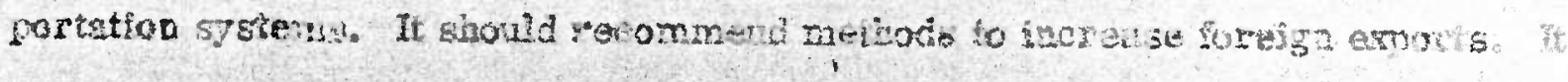

should recommend factibes to vse the aleatric powas trow Catcis Dar.

\section{Labox and Nectrizization}

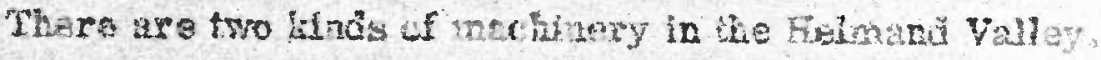

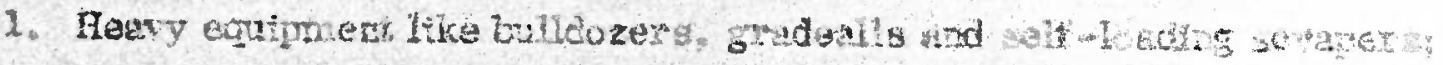

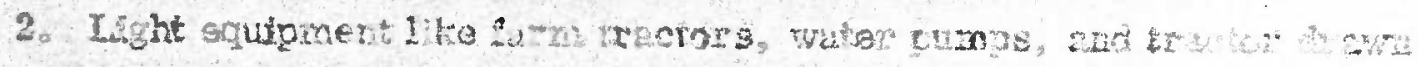
scrapers.

Both clasees of eunpwert fave owe thing in cutrmon: All of

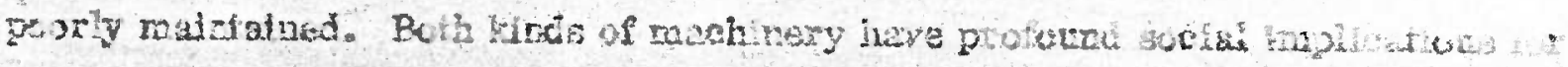
Afghaniwan. 


\section{HAVA has 21 major pieces of beavy agrupneot, This zepreselats an}

ius estanezit of

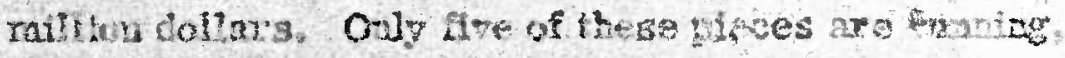

bat only one glooe (the gradeall) is ready for fill tield wae.

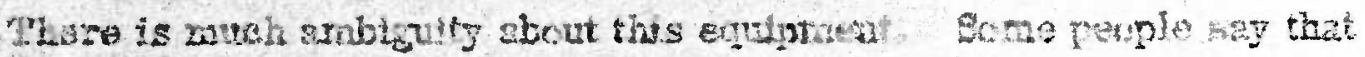

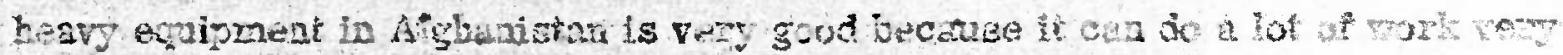

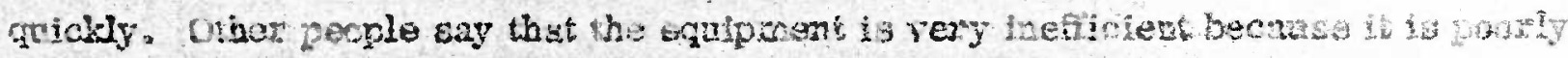

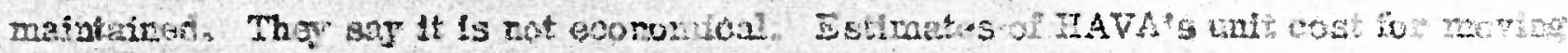

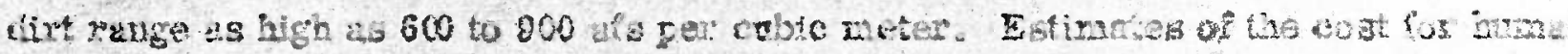

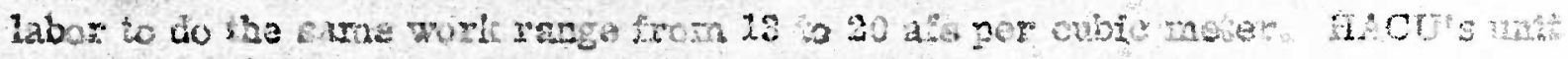

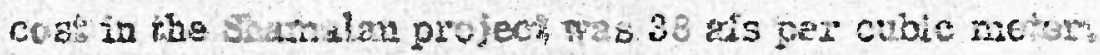

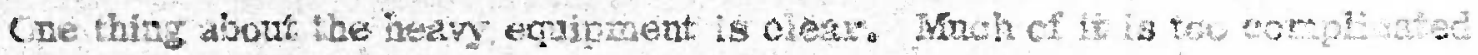

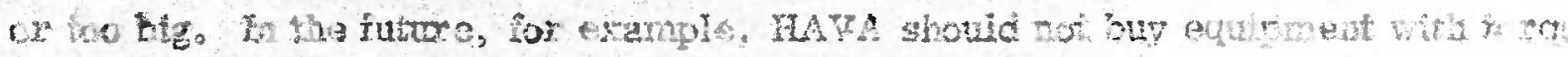

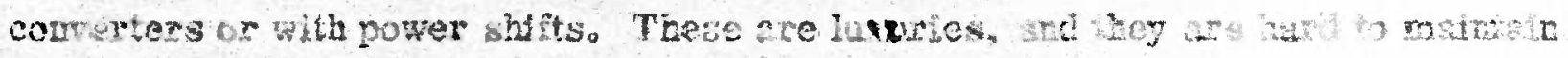

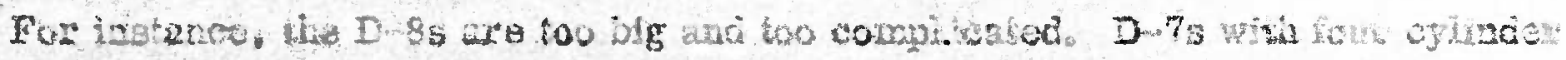

engines would be easiac to mainsila 


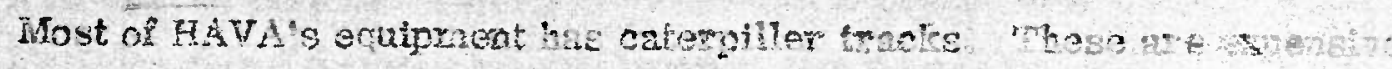

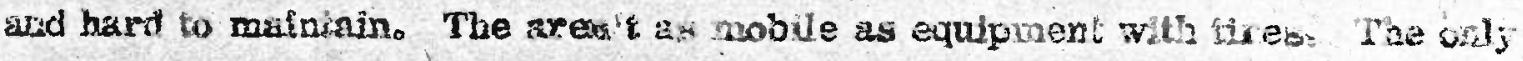

equprnont that, BAYA rovds with tracis are a fer small buldavers.

For gradars it would he better to hive grarlesa wibh a poizitre gear

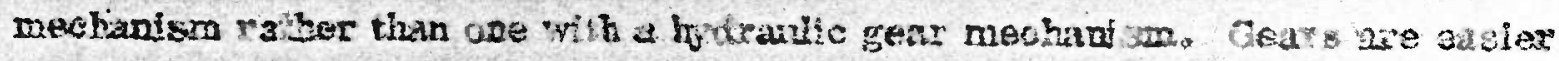

to maintain then hydraulic systeras.

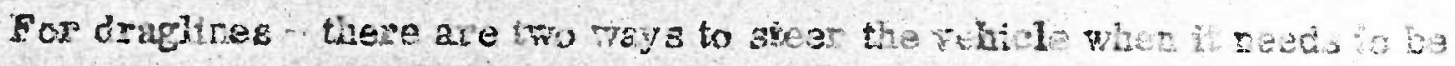

mored from plase to plate. The sophsticated nathines are driret hen inste the

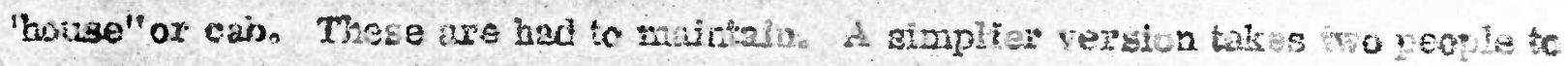

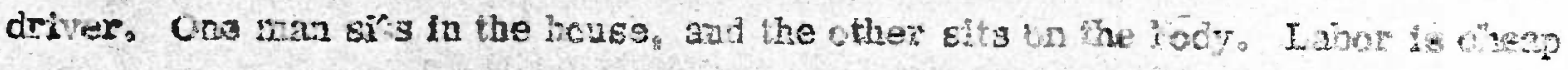

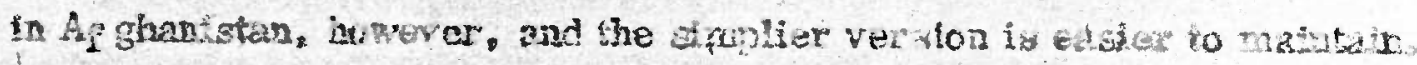

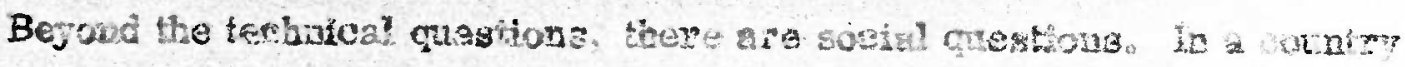

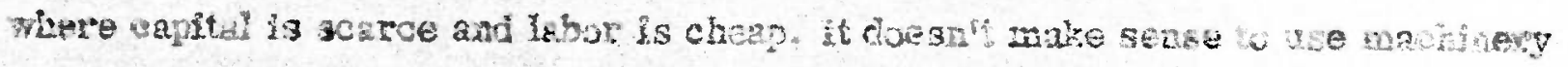

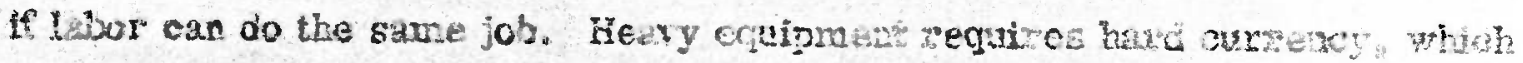

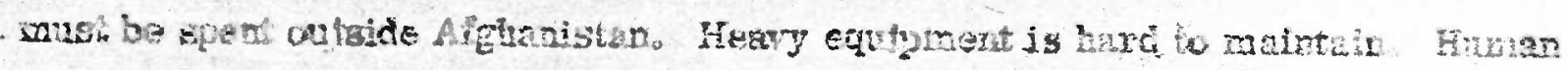

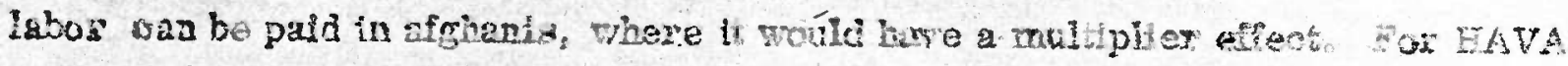

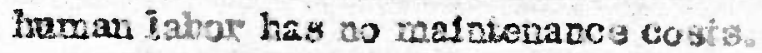


farm equipment as vell. It's poorly natntahed. In the Uwited States mactoses

Deed to be ovexlualled after they have been drtven 4,00 to 5,000 bours in

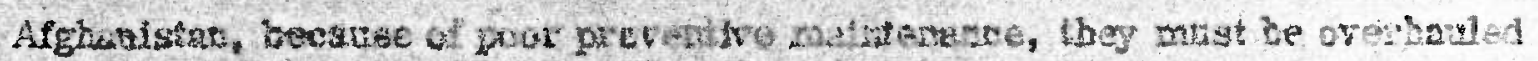

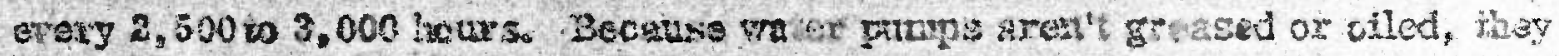

Fun for abcut one-third the thrie thay should run.

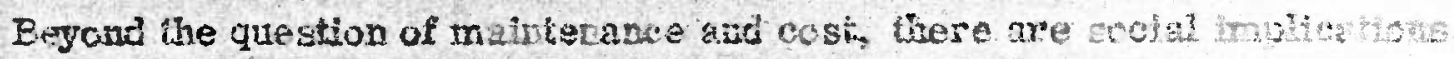

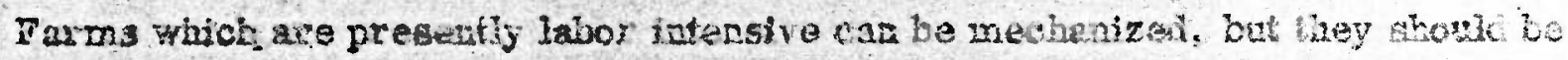

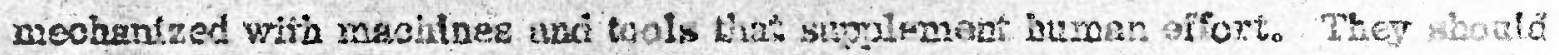

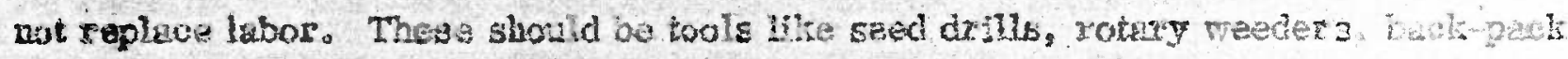

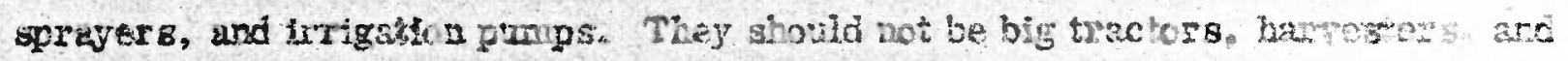

combines. Howerer, the wrong low of mechenization wis beavily gubsicired hrough

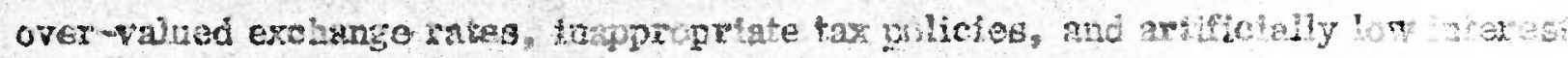

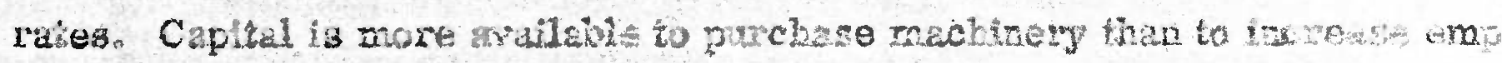

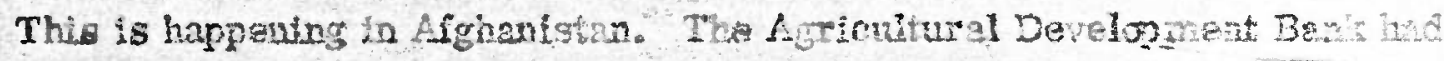

\section{2}

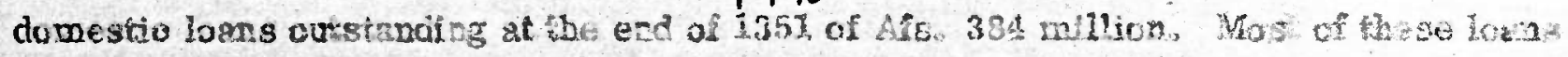

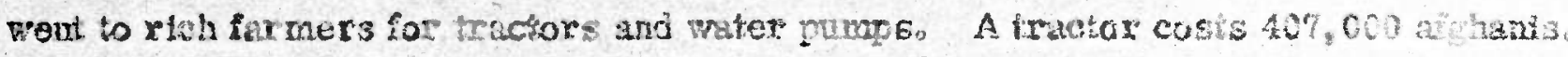


To buy a trector, a turmor must provide a gurety hovi for 600,000 afgethison so

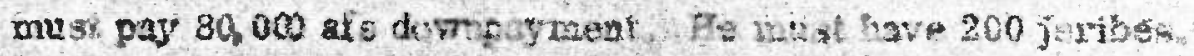

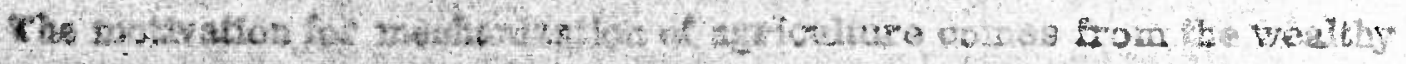

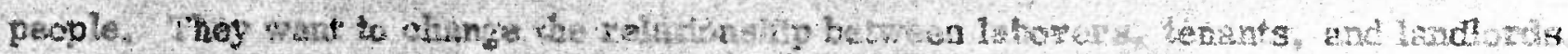

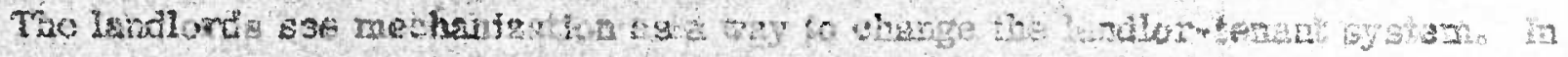

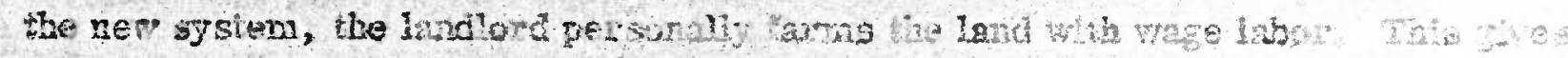

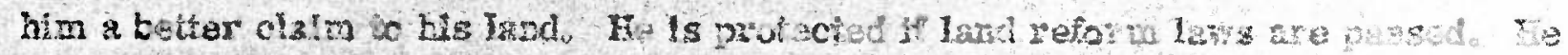

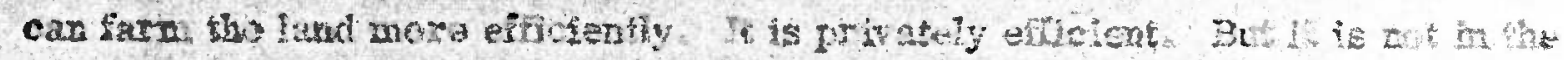

nastonal trierest.

E. Credit

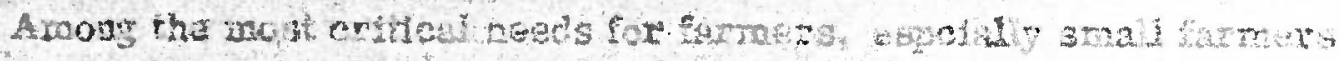

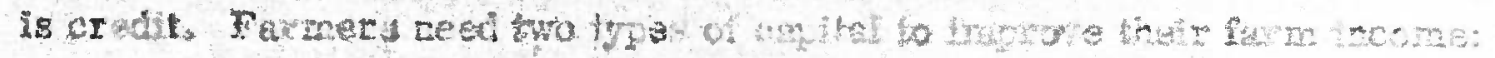

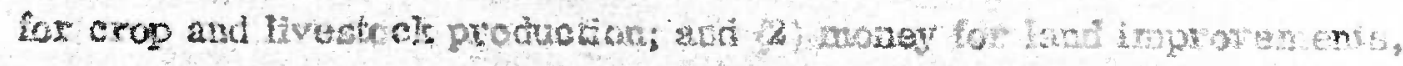

touls and animes.

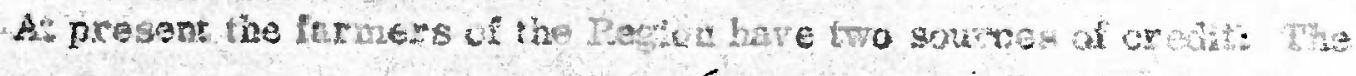

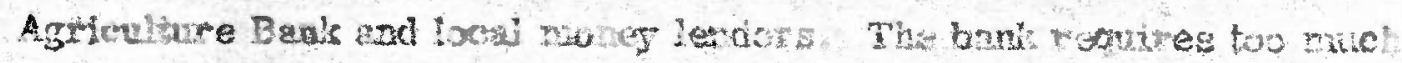




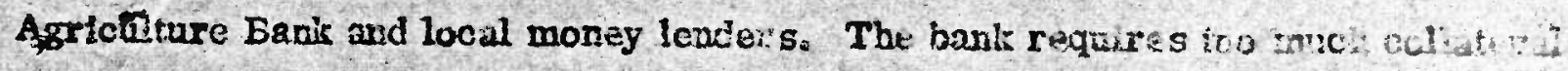

for most farmers. The maney lenders charge 20 to 50 afs par 1,000 per month.

These robes are kureasouble for any farmes.

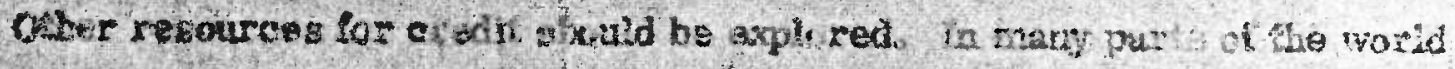

conperatves are zueceestul orfalt instarions, Collateral requirements could be

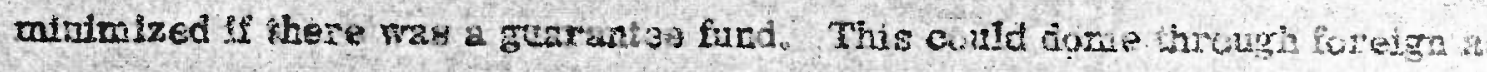

and Goverament funds. If would be administered by the Agricivitul e Ea ko

\section{Electric Powar}

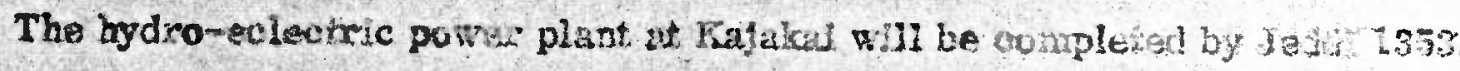

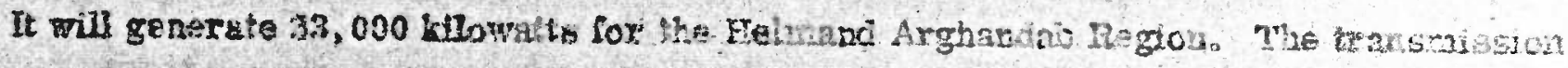

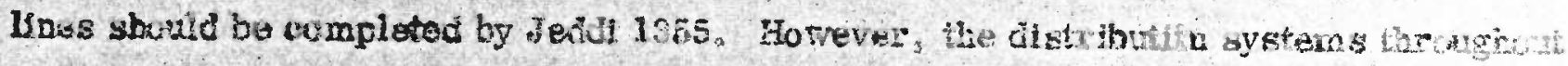

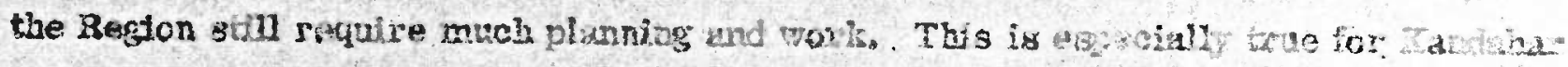

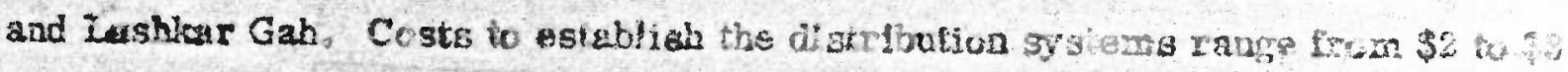

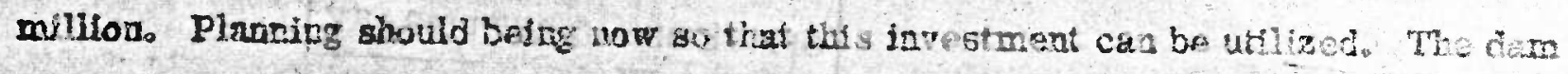

cost $\$ 21$ million. The genejators will cost $\$ 16$ mulion. The transmis ston lines wrib

cost about 87.5 million. All have been or will be financed by loans. 


\section{R \\ $23=$ \\ 5.10 \\ MIT \\ 6397}

ERTA
0
$\alpha A C K U$.
a 